FITRAH Jurnal Kajian Ilmu-ilmu Keislaman

Vol. 03 No. 1 Juni 2017

e-ISSN : 2460-2345, p-ISSN: 2442-6997

Web: jurnal.iain-padangsidimpuan.ac.id/index.php/F

\title{
ETHICAL PROBLEMS RELATED TO LANGUAGE PRACTICE IN ISLAMIC PERSPECTIVE
}

\author{
HAPPY SRI REZEKI PURBA, M.Hum \\ Dosen Universitas Muhammadiyah Tapanuli Selatan
}

\begin{abstract}
In this recent year, the problems that related to Ethical aspect increased significantly including in Language Practice. But ethical aspects are not always clear cut; there are many grey areas that need to be threaded with care by organ religions approach. The writer believes that it is important to understand the ethical problem related to language from Islamic Perspective. Because Islam is the truly faith that can answer all of human's problem. This article aims, first, to identify and classify ethical problems related to language practices and second, to explain the Islamic perspective of ethic including in language practice. The theory of ethics in general and in Islamic perspective also appeared to support the content of this article. Furthermore, the writer hopes that this article can be useful for people who want to study about language practice and ethical problem in Islamic perspective especially.
\end{abstract}

Keywords: Ethical Problem, Language, Islamic Perspective.

\begin{abstract}
Abstrak
Beberapa tahun belakangan permasalahan tentang aspek etika meningkat termasuk juga etika dalam ber bahasa. Tetapi aspek etika tidak selalu berhasil untuk diselesaikan, terlalu banyak wilayah abu-abu yang memerlukan pendekatan agama. Penulis menyakini bahwa diperlukan pandangan Islam dalam memecahkan permasalahan etika berbahasa karena Islam adalah sumber kebenaran hakiki yang dapat menjawab semua masalah manusia. Artikel ini memiliki tujuan pertama, mengidentifikasi dan mengklasifikasi permasalahan etika yang berkaitan dengan bahasa, dan kedua, menjelaskan etika berbahasa dalam pandangan Islam. Article ini juga berisi tentang teori tentang etika secara umum dan pandangan Islam. Selanjutnya, artikel ini diharapkan dapat bermanfaat bagi siapa saja yang ingin melakukan kajian tentang bahasa dan masalah etika dalam pandangan Islam.
\end{abstract}

Kata kunci: Permasalahan etika, Bahasa dan Pandangan Islam. 
FITR AH Jurnal Kajian Ilmu-ilmu Keislaman

Vol. 03 No. 1 Juli 2017

\section{INTRODUCTION}

Ethical problems related to language practice in Islamic perspective have a significant use to avoid the chaos among society especially in this global era. According to the Oxford Dictionary, ethics ${ }^{1}$ is defined as: (1) a system of moral principles by which human actions may be judged as good or bad, right or wrong; (2) the rules of conduct recognized in respect of a particular class of human actions. Delaney (2005) contends that ethics is concerned with the good worth sought in life and with the rules that ought to govern human behavior and human interaction.

Moreover, Nwagboso ${ }^{2}$ believes ethics is in confusion and ferment among all people and he highlights that ethics is not about what person is or what person was, or even about what person will be but ethics is about what ought and have to be. Because of that, Nwagboso thinks ethics is the standard by which person should judge action or character. On the other hand, Hayes, Schilder, Dassen and Wallage (1999) define ethics as a set of moral principles, rules of conduct or values and ethics is relevant when a person has to make a decision from different choices concerning ethical principles.

From an Islamic point of view, ethics is related to several Arabic terms ${ }^{3}$. These terms are as follows: ma'ruf (approved), khayr (goodness), haqq (truth and right), birr (righteousness), qist (equity), 'adl (equilibrium and justice), and taqwa (piety). Good actions are described as salihat and bad actions are described as sayyi'at. However, the term that is most closely related to ethics in the Quran is akhlaq (Beekun 1996). Even though ethics is defined as what is right and wrong, the most pressing issue is how is one to know the right from the wrong (Velasquez 2006).

Especially in language, Islam also emphases that people need to understand the ethic and norm based on this sunnah:

$$
\text { لِسَانِِِ في آدَمَ ابْنِ خَطَايَا أَكْنَرُ }
$$

"Most of Adam's (people) mistake is in his speech". [HR ath-Thabraniy, Abu asy-Syaikh and Ibnu Asakir. Berkata asy-Syaikh al-Albaniy: Hasan, look at

${ }^{1}$ Oxford Dictionary. Oxford University Press. p.393

${ }^{2}$ Al-Hasan al-Aidaros, Ethics and Ethical Theories from an Islamic Perspective, International Journal of Islamic Thought. Vol. 4: (Dec.) 2013

${ }^{3}$ Ibid. p. 2 
Shahih al-Jami' ash-Shaghir: 1201, Silsilah al-Ahadits ash-Shahihah: 534 dan alAdab: 396] $]^{4}$

In language practice, human also need to be able to choose the right and wrong word or sentence. Besides that, people also need to understand the meaning and function of it a society. It will be discuss in syntax, semantics and pragmatics. This article aims, first, to identify and classify ethical problems related to language practices and second, to explain the Islamic perspective of ethic including in language practice.

\section{RELATED LITERATURES}

\section{DEFINITION OF SYNTAX, SEMANTICS AND PRAGMATICS}

In making the clear description of what is syntax, semantics and pragmatics, the writer makes a brief explanation such below:

\section{a. Syntax}

The word syntax comes from Ancient Greek "coordination", which

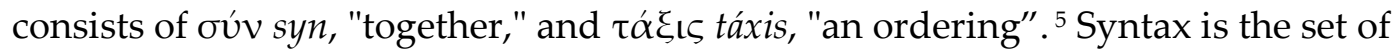
rules, principles, and processes that govern the structure of sentences in a given language, specifically word order. The term syntax is also used to refer to the study of such principles and processes. The goal of many syntacticians is to discover the syntactic rules common to all languages. Syntax (in the philosophical use of the term) refers to the vocabulary and the rules of sentence formation of a language. These rules are called the grammar of language and they guide the construction of complicated expressions from terms and atomic sentences.

A basic feature of a language's syntax is the sequence in which the subject $(\mathrm{S})$, verb $(\mathrm{V})$, and object $(\mathrm{O})$ usually appear in sentences. Over $85 \%$ of languages usually place the subject first, either in the sequence SVO or the sequence SOV. ${ }^{6}$ The other possible sequences are VSO, VOS, OVS, and OSV, the last three of which are rare.

${ }^{4}$ Abu Ubaidillah Al-Faruq, Cinta Kajian Sunnah, Retrived From Cinta Kajian Sunnah Wordpress, Kebanyakan Dosa Anak Adam itu adalah karena Lisannya, at 11 January 2017 at $2 \mathrm{pm}$.

5https://en.wikipedia.org/wiki/Syntax retrieved at 11 January 2017, 3 pm

${ }^{6}$ Al-Hasan al-Aidaros, Ethic......, 2013, p.4 
FITR AH Jurnal Kajian Ilmu-ilmu Keislaman

Vol. 03 No. 1 Juli 2017

In short, syntax can be concluded as the arrangement of words and phrases to create well-formed sentences in a language or structure of statements in a computer language.

\section{b. Semantics}

Semantics (from Ancient Greek semmantikos, "significant") is primarily the linguistic, and also philosophical study of meaning in language, programming languages, formal logics, and semiotics. ${ }^{7}$ It focuses on the relationship between signifier like words, phrases, signs, and symbols and what they stand for, their denotation. Semantics is the branch of linguistics and logic concerned with meaning. The two main areas are logical semantics, concerned with matters such as sense and reference and presupposition and implication, and lexical semantics, concerned with the analysis of word meanings and relations between them.

The word semantics was first used by Michel Bréal, a French philologist. -It denotes a range of ideas-from the popular to the highly technical. It is often used in ordinary language for denoting a problem of understanding that comes down to word selection or connotation. This problem of understanding has been the subject of many formal enquiries, over a long period of time, especially in the field of formal semantics. In linguistics, it is the study of the interpretation of signs or symbols used in agents or communities within particular circumstances and contexts. Within this view, sounds, facial expressions, body language, and proxemics have semantic (meaningful) content, and each comprises several branches of study. In written language, things like paragraph structure and punctuation bear semantic content; other forms of language bear other semantic content. ${ }^{8}$

Semantics has two major meanings. First, semantics is the system of meaning relations that are obtained between language and reality; second, semantics is the study of the representative function and meaning of linguistic expressions. In this latter sense, semantics is the analysis of the relationships between expressions and their referents. Thus, semantic studies pay attention to the representational capacity of language, whereas syntactic study focuses solely on the internal aspects of language, especially on terminology, grammar, and analytical and logical relations between terms and between sentences.

7https://en.wikipedia.org/wiki/semantics retrieved at 12 January 2017, $3.10 \mathrm{pm}$

${ }^{8}$ Al-Hasan al-Aidaros, Ethics, ...., 2013, p. 5. 


\section{c. Pragmatics}

Pragmatics is a subfield of linguistics and semiotics that studies the ways in which context contributes to meaning. Pragmatics encompasses speech act theory, conversational implicature, talk in interaction and other approaches to language behavior in philosophy, sociology, linguistics and anthropology. ${ }^{9}$ Unlike semantics, which examines meaning that is conventional or "coded" in a given language, pragmatics studies how the transmission of meaning depends not only on structural and linguistic knowledge (e.g., grammar, lexicon, etc.) of the speaker and listener, but also on the context of the utterance, any pre-existing knowledge about those involved, the inferred intent of the speaker, and other factors. In this respect, pragmatics explains how language users are able to overcome apparent ambiguity, since meaning relies on the manner, place, time etc. of an utterance.

Moreover, Pragmatics is the study of the use of linguistic signs, especially sentences, in actual or imaginary situations. A pragmatic study of language can concern, for example, the users of language and their goals of and interests in using language. Often pragmatics also concerns the relationship between different linguistic practices, contexts, and meanings. Thus, pragmatics studies the question of how meanings depend on a context and on different uses of the same linguistic expressions.

\section{ETHICS: THEORY AND CONCEPT}

\section{a. Concept of Ethics}

In the case of our theme (i.e., ethical questions related to language), it is also important to have at least a tentative understanding of the concept and theory of ethics. The following characterization attempts to take into consideration several often-mentioned dimensions of ethics. First, ethics refers to valuations and prescriptive (i.e., commanding or prohibitive) notions that aim to regulate the action and behaviour of all people irrespective of gender, origin, social class, or another specific characteristic. Second, based on these prescriptive notions, acts, intentions and consequences of acts are judged to be good or bad, right or wrong. Moral evaluation, which is an essential aspect of ethics, is also 
FITR AH Jurnal Kajian Ilmu-ilmu Keislaman

Vol. 03 No. 1 Juli 2017

(and often primarily) directed at the doers of acts who are praised or blamed (as the agent of the act) and are called good or bad, just or unjust. ${ }^{10}$

One could expect that in so far as ethics concerns human practices, action, and behaviour, the consideration of ethical questions related to language must primarily revolve around the pragmatic dimension of language. Thus, there is at least a tentative reason to think that of the three dimensions of language, pragmatics is the most relevant for ethical considerations. However, it is worth considering whether there are any special ethical problems related to syntax or semantics. As an advance answer, it can be said that yes, there are some special cases of philosophically interesting, ethical issues that concern syntax and semantics. Those issues also concern the pragmatics of language, but nevertheless they are primarily related to syntax and semantics. Such issues are, for example, swearing, translation mistakes, the choosing of words for a dictionary, and ignorance of a language. In what follows, examples of these issues are considered more closely.

Thus, borrowing the division presented by Morris, we can structure the ethical questions related to language into syntactic, semantic, and pragmatic categories. Accordingly, the questions of syntactic category concern the ethical problems related to the vocabulary and grammar of a language. The questions of semantic category concern the ethical problems related to the linguistic representation of reality, and the questions of pragmatic category concern the ethical problems related to linguistic practices.

\section{b. Theory of Ethics in Global and Islamic Perspective}

\section{1) Relativism theory}

Relativism theory proposes that ethical values are relative to a particular environment or location. It discusses that moral values can be different from one culture to another, from one time to another. According to this theory, there are no moral principles that are completely right, relevant and applicable to companies and people of all countries . ${ }^{11}$

This implies that: (a) different countries and societies may have different ethical codes; (b) there is no standard or principle that can be used to

${ }^{10}$ Tommi Lehtonen, Ethical Problems Related to Language and Linguistic Practices University of Vaasa, N:o 38. Vaasa 2011, P. 202

${ }^{11}$ Al-Hasan al-Aidaros, Ethics......, 2013, p.3 
evaluate one societal code better than the other; (c) the ethical code of specific society has no special rank, which means it is simply one among many; (d) there is no universal truth in moral/ethical principles that can be held for all peoples at all times; and (e) the moral code of a specific country or society identifies what is right within that society; if the moral code of that country or society says that a certain action is right, then that action is right at least within that society.

From the Islamic point of view, relativism theory is also problematic. According to Islam, what is right and what is wrong cannot be left to a particular society because human beings have inherent weaknesses in that they will tend to behave in a manner that they see is convenient, regardless of whether such action is right or wrong. This is why Muslims have to base their actions on the words of Allah (the Quran) and the Sunnah of the Prophet. For this reason, Islam rejects relativism theory. However, Islam also respects the culture of any society as long as it is not against what is Islamically prescribed. For example, the Prophet Muhammad recognizes acts such as telling the truth (Al-Quran 9:119) as morally right and rejects other acts such as killing a newborn girl as being morally wrong (Al-Quran 81:8/9).

\section{2) The Divine Command Theory}

The Divine Command Theory truth about that issue or that all viewpoints about that issue are equally acceptable. When two people or two groups have different viewpoints, theorists as well as researchers are fond of pointing out that at least one of them is wrong. Also, this theory would make little sense to disapprove the practices of other societies as long as their practices conform to their own principles and values. For example, practically this means that multinational companies should not be judged to act in a rightful or wrongful manner since they do so according to different prescribed cultures. ${ }^{12}$

From the Islamic point of view, relativism theory is also problematic. According to Islam, what is right and what is wrong cannot be left to a particular society because human beings have inherent weaknesses in that they will tend to behave in a manner that they see is convenient, regardless of whether such action is right or wrong. This is why Muslims have to base their actions on the words of Allah (the Quran) and the Sunnah of the Prophet. For

${ }^{12}$ Al-Hasan al-Aidaros, Ethics....., 2013, p. 6. 
FITR AH Jurnal Kajian Ilmu-ilmu Keislaman

Vol. 03 No. 1 Juli 2017

this reason, Islam rejects relativism theory. However, Islam also respects the culture of any society as long as it is not against what is Islamically prescribed. For example, the Prophet Muhammad recognizes acts such as telling the truth (Al-Quran 9:119) as morally right and rejects other acts such as killing a newborn girl as being morally wrong (Al-Quran 81:8/9).

\section{3) Consequences Theories}

Consequence theories, utilitarian theory and egoism theory, look at the consequences of any action to determine whether an act is right or wrong. In utilitarian theory, an act is considered to be morally right if it brings the greatest good for the greatest number. An action must do the most good and does the least harm. In contrast, egoism theory is concerned about the consequences of the greatest good for the person only without considering the consequences on others. The next section will discuss these theories in more detail. ${ }^{13}$

\section{4) Egoism Theory}

The general idea of egoism theory is that one must always perform in his/her own interest. An action is considered to be morally right when it promotes a person's self-interests more than the interests of others. In other words, egoism theory assumes that each person ought to follow his/her own self-interest exclusively. This means that a person does not have an ethical duty except to do what is best for him/her.

As a result, critics argue that egoism theory is unacceptably logical because people must care about the interests of other people for the same reason they care about their own interest. Armstrong indicates that egoism theory is relevant to business schools as businesses are in search of maximization of profits as their prime objective. However, this theory repeatedly results in conflict of interest and cannot always be adapted to the mission of serving public and clients' interests like in the accounting profession. Moreover, egoism theory might be in conflict with the principles of accountants' ethical code of conduct as accountants must have objectivity, integrity, due care, and protect public interest. Consequently, egoism theory has its limitation as a sufficient ethical theory for accountants. Egoism theory is not acceptable in Islam because it is essentially against the Islamic principles of justice, helping others, and altruism.

${ }^{13}$ Al-Hasan al-Aidaros, Ethics......, 2013, p. 7. 
According to Prophet Muhammad, a Muslim has no iman (faith) until he loves his brother as he loves himself. Muslims are strongly encouraged to be considerate and help others without looking for material rewards from the society. Doing so, they will receive rewards in the Hereafter as Allah promised and mentioned in several places in the Quran $(5: 54 ; 48: 29 ; 59: 9 ; 107: 3)$.

\section{5) Utilitarian Theory}

Utilitarianism is a common term for any view that holds that procedures and actions should be evaluated on the basis of the benefits and costs they impose on society. Utilitarian theory argues that a behavior is considered morally right when it results in a greater number of utilities than it could be achieved by any other action. Utilitarian theory and egoism theory both consider the consequences of an action with different approaches of evaluating an ethical conduct. Egoism theory focuses on the consequences for the self, whereas utilitarian theory focuses not only for the self but also for as many as possible. ${ }^{14}$

Generally speaking, Islam does not accept any wrong doing, for example, stealing or cheating, regardless of whether it brings greater good for the society or not. In view of that, Islam does not accept utilitarian theory as a sufficient theory because this theory considers ethics as having the greatest consequences for the greatest number, when some actions may be inherently wrong. From the Islamic perspective, Muslims must follow the right ethics in accordance to Islamic principles (Al-Quran 59:7). The Islamic system takes care of the interests of everyone in the society because of the universal ethical values and principles imposed by the religion.

\section{6) Deontology Theory}

Deontology theory underlines duty as a basic moral category. This theory also focuses on universal statements of right and wrong. However, unlike utilitarian theory, this theory is not concerned with the consequences of the action, which means that the action is independent in itself (Ho 2007). In other words, the theory argues that a person has a duty to do what is right without having to consider the consequences of his/her action (Ho 2007). The most representative supporter of deontology theory is Immanuel Kant, a German philosopher in the 18th century. Kant believed that there are universal ethics that everyone must accept, for example, "never do something unless you

${ }^{14}$ Al-Hasan al-Aidaros, Ethics, ....2013, p. 8. 
FITR AH Jurnal Kajian Ilmu-ilmu Keislaman

Vol. 03 No. 1 Juli 2017

are willing to have everyone done it" (Velasquez 2006). Another example of Kant's universal ethics is "Never use people merely as means, but always respect and develop their ability to choose for themselves". ${ }^{15}$

Critics such as Velasquez (2006) argue that deontology theory's categorical imperatives are unclear because the theory only considers the duty or the action independently without looking at the consequences. It can be in conflict with the normative understanding of people and sometimes it implies some mistaken ethical conclusions. In applying deontology theory to accounting practices, professional accountants may find it difficult to deal with the conflict of duties for different stakeholders.

Deontology theory is also not acceptable in an Islamic context because the only lawgiver for the overall system, including the ethical system, is Allah s.w.t (Al-Quran 16:86). The Prophet Muhammad (peace and prayers be upon him) advised his followers (or sahabah) to treat others as how they like others to treat them. Furthermore, Islam encourages Muslims not only to treat people with justice but to treat others better than how they treat them. Allah s.w.t says in the Quran (41:34): "Nor can goodness and evil be equal. Repel (evil) with what is better".

\section{7) Virtue Ethics Theory}

Virtue ethics theory defines what is right and wrong based on specific traits and values every person must follow. According to this theory, the purpose of an ethical life is to develop general characters called ethical virtues, and to apply and exhibit them in reality. Unlike previous theories such as consequences theories and deontology theory that are concerned about an individual's action, virtue ethics theory focuses on the self. Virtue ethics theory concentrates on the question of what people should be rather than of what they should $\mathrm{do}^{16}$.

In other words, this theory focuses on what makes a good individual or person rather than what makes a good action. The most representative supporter of virtue ethics theory is Aristotle. Aristotle proposed several virtue traits that every person must have. They are civility, cooperativeness, courage, fairness, friendliness, generosity, honesty, justice, loyalty, self-confidence, selfcontrol, modesty, fairness, and tolerance. Virtue ethics theory has limitations to

\footnotetext{
${ }^{15}$ Al-Hasan al-Aidaros, Ethics...., 2013, p. 5

${ }^{16}$ Al-Hasan al-Aidaros, Ethics....., 2013, p. 8.
} 
answer question like what are the sources of these ethics. In addition, loyalty ethic, as a product of this theory, may guide to conflict with the requirements of the accounting profession for being independent.

In contrast, Islam considers both ethical actions and virtue ethics, not just only one criterion as contended by virtue ethics theory that is based on the character (Mohammed 2005). In Islam every person must behave according to specific ethical characteristics, but the sources of these characteristics are Quran and Sunnah (Prophet Muhammad's saying, practice and approvals) (AlQuran 31:77; Mohammed 2005). Besides, in Islam, individuals have a very clear picture about what is right and wrong as enshrined in the Quran and Sunnah (AlQaradawi 1985; Al-Quran 58:7).

As a summary, to determine whether an action or decision is ethically carried out, ethical theories, developed mainly by Western scholars, are the current theoretical framework organizations have at their disposal. Theories such as relativism, utilitarianism, egoism, deontology, and the virtue ethics, are all products of Western understanding of what ethics are and how they are applicable to help one's decision-making process. Every theory has a single viewpoint with regard to ethical issues, as shown in Figure 1 like action, character, religion, or culture. In contrast, Islam conceptualizes ethics based on the Islamic sources.

Islam goes even further than these theories by maintaining that all systems, including the ethical system, are in the hands Allah s.w.t. While Islam agrees with divine command theory, which was rejected in the Western ethical literature, it has different considerations as mentioned earlier. In order to get a clear understanding of ethics from the Islamic perspective, the next section will explain a general framework of ethics in Islam. The main idea of the Islamic ethical theory is that the Islamic sources are the only standard for identifying what is right and what is wrong.

\section{ETHICAL PROBLEM RELATED TO LANGUAGE IN ISLAMIC PERSPECTIVE}

This ethical Problem related to language described in three big majors: from syntax, semantics and also pragmatics. First, in syntax; vocabulary and grammar can be relevant for moral considerations only in relation to their use and application in linguistic practices. The moral relevance of terminology and 
FITR AH Jurnal Kajian Ilmu-ilmu Keislaman

Vol. 03 No. 1 Juli 2017

grammar requires, first, their use in linguistic practices and, second, moral rules concerning linguistic behaviour and communication. For example, if someone uses bad language, curses, or cusses in public, she may be reproached for bad manners and for disrespect for other people. This is certainly a different reproach than, for example, being blamed for flawed pronunciation or grammar mistakes ${ }^{17}$.

In all cultures some linguistic (and non-linguistic) expressions are considered reprehensible and people can be blamed for bad language, taboo words, or curse words. In such cases, the criticism is placed not necessarily on certain words as such, but on the use of the words if the use is thought to be intentionally insulting and offensive. Thus, although the criticism concerns syntactical units, individual words, or longer expressions, the criticism is directed towards the use and users of them. In such cases, the nature and direction of the criticism is pragmatic rather than syntactic.

A similar problem of impoliteness and rudeness that is related to taboo words also concerns other words and expressions that have an offensive, sarcastic, or discriminatory tone (and that are used intentionally to insult or offend someone). However, some people might prefer to exclude bad words not only from actual use but also from dictionaries, because some words as such are considered to be morally wrong.

In qur'an, Allah commands His servant Muhammad SAW to tell the believing servants of Allah that they should address one another in their conversations and discussions with the best and politest of words, for if they do not do that, Shaytan will sow discord among them, and words will lead to actions, so that evil and conflicts and fights will arise among them ${ }^{18}$ For Shaytan is the enemy of Adam and his descendants, and has been since he refused to prostrate to Adam. His enmity is obvious and manifest. For this reason it is forbidden for a man to point at his Muslim brother with an iron instrument, for Shaytan may cause him to strike him with it. (Imam Ahmad recorded that Abu Hurayrah said: "The Messenger of Allah said:

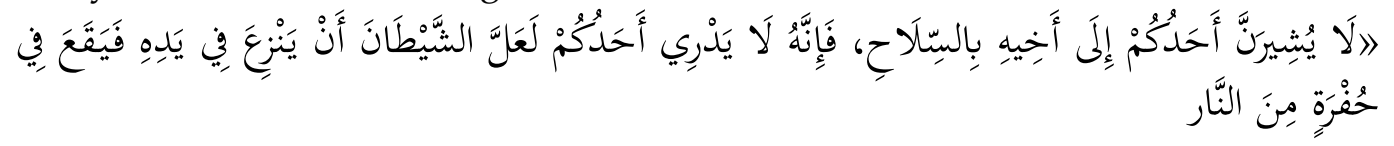

17Tommi Lehtonen, Ethical Problems......., 2011. P. 203.

${ }^{18} \mathrm{Ibnu}$ Kasir, Alquran Tafsir Retrived from http://www. at 10 Januari 2017, 09.00 pm. 
(No one of you should point at his brother with a weapon, for he does not know whether Shaytan will cause him to strike him with it and thus be thrown into a pit of Fire.) Al-Bukhari and Muslim recorded this Hadith with the chain of narration from 'AbdurRazzaq.

Through the above explanation, it can be concluded that Islam also asked the people to use a good word in good order and grammatical. It is very important because the politeness is one of the characteristics of Islamic people and as the reflection of ethic in Islam. In Islam every person must behave according to specific ethical characteristics, but the sources of these characteristics are Quran and Sunnah (Prophet Muhammad's saying, practice and approvals) (AlQuran 31:77; Mohammed 2005). Besides, in Islam, individuals have a very clear picture about what is right and wrong as enshrined in the Quran and Sunnah (Al-Qaradawi 1985; Al-Quran 58:7).

The second is semantics. A special ethical issue related to semantics arises from the ignorance and erroneous beliefs of language users. The issue in question concerns the ability and competence of language users to refer to intended objects or to intended views or concepts. If a language user manages to refer to the referent of the expression used (and to the object she intends to refer to), then the basic requirement of a successful linguistic communication is met. ${ }^{19}$

However, if she fails to refer, an uncertainty or a misconception is created among her audience. This issue is related to the general demand to communicate in a way that the audience can rightly understand what is being said. Thus, it is potentially an ethical problem related to the semantics of a language if a writer or speaker fails to refer to the object to which she intends to refer.

Such a failure may easily take place, for example, if the referent-object in question is not known to the writer or speaker herself either by acquaintance or by description. Consequently, it may be ethically questionable to speak or write about a subject matter that is totally (or largely) unknown to the author. Thus, one should avoid speaking and writing about topics of which one is ignorant, or at least, in such cases, our moral duty is to be especially careful about what we say and to make clear that we are not experts.

In other words, people need to use a clear word and honest. In Islam Allah SWT asked us to be honest in speaking so other people can get the meaning of our words in right perception. There are many surah in Qur'an that

${ }^{19}$ Tommi Lehtonen, Ethical Problems...., 2011. p. 206. 
FITR AH Jurnal Kajian Ilmu-ilmu Keislaman

Vol. 03 No. 1 Juli 2017

emphasized us the importance of honest in speaking. One of the surah is: "O you who believe! Fear God, and be with those who are true (in word and deeds)." (Quran 9:119) Ibn Katheer, the renowned Quran scholar, explained the meaning of this verse. He said, "Being truthful and adhering to truthfulness, means you will be among the people of the truth and be saved from calamity and that it will make a way out for you from your problems".

A true believer, one who is truly submitted to God, has many characteristics by which he can be identified. The most obvious of these noble characteristics are honesty of character and truthfulness of speech. Prophet Mohammad was a perfect example of honesty. Even before his Prophethood, he had earned the titles of Al Amin (the trustworthy one) and As Sadiq (the truthful).

The third, is pragmatics. Pragmatics is the study of the use of linguistic signs, especially sentences, in actual or imaginary situations. ${ }^{20}$ The largest category of ethically relevant, linguistic issues is related to pragmatics, that is, the use of language. A general feature of language that makes the moral evaluation of linguistic practices relevant is that language is a means of social inclusion and exclusion. In books such as Madness and Civilization, The History of Sexuality, and Discipline and Punishment, Michel Foucault famously studied the ways in which certain social groups are marginalized by the discourses of more powerful groups. Foucault also studied social mechanisms that determine who can competently engage in a public debate on a given topic. These power mechanisms and positions of dominance are apt to be morally problematic. This does not mean, in any way, that all linguistic practice even political or economic talk that obviously involves a power dimensions are morally wrong.

Language users can also be ethically criticized, for example, for gossiping, boasting, double-speak, and the misleading use of rhetorical means such as metaphors, similes, and hyperbole. Especially in this social media era, the language users commonly used language for posting something unimportant and can cause conflict.

Indeed, Islam also concern about this field. Islamic people have to avoid gossiping, boasting and also unimportant speech because HR ath-Thabraniy said: أكُتَرُ خَطَايَا ابْنِ آَدَمَ فِي لِسَانِهِ

20Tommi Lehtonen, Ethical Problems...,,2011. p. 207 
"Most of Adam's (people) mistake is in his speech". [HR ath-Thabraniy, Abu asy-Syaikh and Ibnu Asakir. Berkata asy-Syaikh al-Albaniy: Hasan, look at Shahih al-Jami' ash-Shaghir: 1201, Silsilah al-Ahadits ash-Shahihah: 534 dan al-Adab: 396]. ${ }^{21}$

\section{CLOSING}

From an Islamic point of view, ethics is related to several Arabic terms. These terms are as follows: ma'ruf (approved), khayr (goodness), haqq (truth and right), birr (righteousness), qist (equity), 'adl (equilibrium and justice), and taqwa (piety). Good actions are described as salihat and bad actions are described as sayyi'at.

The ethical Problem related to language described in three big majors: from syntax, semantics and also pragmatics. First, in syntax; vocabulary and grammar can be relevant for moral considerations only in relation to their use and application in linguistic practices. The second is semantics. A special ethical issue related to semantics arises from the ignorance and erroneous beliefs of language users. The issue in question concerns the ability and competence of language users to refer to intended objects or to intended views or concepts. The third, is pragmatics. Pragmatics is the study of the use of linguistic signs, especially sentences, in actual or imaginary situations. The largest category of ethically relevant, linguistic issues is related to pragmatics, that is, the use of language.

Language is a tool of communication that can help people to understand each other, Allah SWT created people with the ability to acquire and use language. As perfect creator, people should use language in ethically and for useful point such advising someone to do a good thing and for kindness.

${ }^{21}$ Abu Ubaidillah Al-Faruq, Cinta Kajian Sunnah.....2017, at 11 January 2017 at 2 pm. 
FITR AH Jurnal Kajian Ilmu-ilmu Keislaman

Vol. 03 No. 1 Juli 2017

\section{REFERENCES}

Abu Ubaidillah Al-Faruq, Cinta Kajian Sunnah, Retrived From Cinta Kajian Sunnah Wordpress, Kebanyakan Dosa Anak Adam itu adalah karena Lisannya, at 11 January 2017 at 2 pm.

Abu Ubaidillah Al-Faruq, Cinta Kajian Sunnah.....2017, at 11 January 2017 at 2 pm.

al-Aidaros, Al-Hasan, Ethics and Ethical Theories from an Islamic Perspective, International Journal of Islamic Thought. Vol. 4: (Dec.) 2013

Ibnu Kasir, Alquran Tafsir Retrived from http://www. at 10 Januari 2017, 09.00 pm.

Oxford Dictionary. Oxford University Press. t.t.

Tommi Lehtonen, Ethical Problems Related to Language and Linguistic Practices University of Vaasa, N:o 38. Vaasa 2011.

\section{Sumber Internet:}

https://en.wikipedia.org/wiki/Syntax retrieved at 11 January 2017, 3 pm

https://en.wikipedia.org/wiki/semantics retrieved at 12 January 2017, 3.10 pm

https://en.wikipedia.org/wiki/pragmatics retrieved at 13 January 2017, 3.15 pm 